\title{
Production of Aspartic Acid and Enzymatic Alteration in Pyruvate Kinase Mutants of Brevibacterium flavum
}

\author{
Michiko MoRI and Isamu SHIIO \\ Central Research Laboratories, Ajinomoto Co., Inc., \\ Kawasaki-Ku, Kawasaki, Kanagawa 210, Japan
}

Received September 20, 1983

\begin{abstract}
A pyruvate kinase-lacking mutant of Brevibacterium flavum produced $22.6 \mathrm{~g} /$ liter of L-aspartic acid with glutamic acid as a by-product, when cultured for $48 \mathrm{hr}$ in a medium containing $100 \mathrm{~g} /$ liter of glucose. The production clearly depended on the amount of biotin added. This strain, 70 , was derived by several steps of mutation from wild strain 2247 producing glutamate, successively via a citrate synthase-defective glutamate auxotroph, strain 214 , a prototrophic revertant, strain $15-8$, producing $10 \mathrm{~g} /$ liter of L-aspartic acid, and an $S$-(2-aminoethyl)-L-cysteine-resistant mutant, strain 1-231, having low pyruvate kinase and homoserine dehydrogenase and producing lysine. Strain 70, a methionine-insensitive revertant from strain 1-231, had a normal level of homoserine dehydrogenase but no pyruvate kinase. Its citrate synthase activity was about half that of the wild strain at saturated concentrations of the substrates with Michaelis constants for oxalacetate and acetyl$\mathrm{CoA}$ of 110 and 6 times as high as those of the wild-type enzyme, respectively. The mutational step for these alterations in citrate synthase was strain 15-8. Phosphoenolpyruvate carboxylase of strain 70 showed 1.5 -fold higher activity in the crude extract at saturated concentrations of phosphoenolpyruvate, a lower Michaelis constant $(1.5 \mathrm{~mm})$ for the substrate, phosphoenolpyruvate, less sensitivity to the feedback inhibition by aspartate, and higher sensitivities to the activators, acetylCoA and fructose-1,6-bisphosphate, than those of the wild strain. The concentrations of aspartate giving $50 \%$ inhibition were 6.2 - and 4.5 -fold higher in the absence and presence of acetyl-CoA, respectively.
\end{abstract}

In the previous study, a prototrophic revertant, 15-8, derived from a citrate synthase (CS)-defective glutamate auxotroph of Brevibacterium flavum, produced $10 \mathrm{~g} /$ liter of L-aspartic acid with a $30 \%$ yield, whereas the wild strain produced a large amount of Lglutamic acid but only a small amount of $\mathrm{L}$ aspartic acid, when they were cultured with a limited amount of biotin. ${ }^{1)}$ Further studies revealed that the concentration of $\mathrm{L}$-aspartate produced by strain 15-8 was not increased by increasing the concentration of the carbon source, glucose, in the culture medium, indicating that it was still subject to the feedback control of phosphoenolpyruvate (PEP) carboxylase (PC) by aspartate (Fig. 1). Therefore, removal of the feedback inhibition of PC as well as an increase in the intracellular con- centration of PEP, the substrate competing with the inhibitor, may increase the production of L-aspartate. Of these, the feedback inhibition of PC has been partially removed in strain 15-8. Moreover, a mutant having low pyruvate kinase (PK)-activity has already been derived from strain 15-8 and isolated as a lysine producer, in which the PEP concentration seems higher than in the wild-type strain. ${ }^{4)}$

The present paper reports an increase of the L-aspartate production with a lack of $\mathrm{PK}$ as well as mutational alteration of the related enzymes (Fig. 1) in the producers.

\section{MATERIALS AND METHODS}

Bacterial strains and culture media. Bacterial strains used

Abbreviations: PC, phosphoenolpyruvate carboxylase; PK, pyruvate kinase; CS, citrate synthase; TA, aspartate aminotransferase; HD, homoserine dehydrogenase; PEP, phosphoenolpyruvate; OAA, oxalacetate; AcCoA, acetylCoA; DTNB, 5,5'-dithiobis-(2-nitrobenzoic acid) 
TABle I. Bacterial Strains Used

\begin{tabular}{lllc}
\hline Strain & Parent & \multicolumn{1}{c}{ Remarks } & References \\
\hline 2247 & - & $\begin{array}{l}\text { Brevibacterium flavum, a wild strain producing glutamate } \\
\text { CS-deficient glutamate auxotroph producing aspartate }\end{array}$ & 5 \\
214 & 2247 & $\begin{array}{l}\text { Prototrophic revertant with low CS and feedback-less sensitive } \\
\text { PC, producing aspartate }\end{array}$ & 1,4 \\
$15-8$ & 214 & AEC-resistant mutant with low PK and HD, producing lysine & 1,4 \\
70 & $15-8$ & Methionine-insensitive revertant with normal HD, & This paper \\
& $1-231$ & producing aspartate & \\
\hline
\end{tabular}

Abbreviations: CS, citrate synthase; PC, phosphoenolpyruvate carboxylase; PK, pyruvate kinase; HD, homoserine dehydrogenase; AEC, $S$-(2-aminoethyl)-L-cysteine.

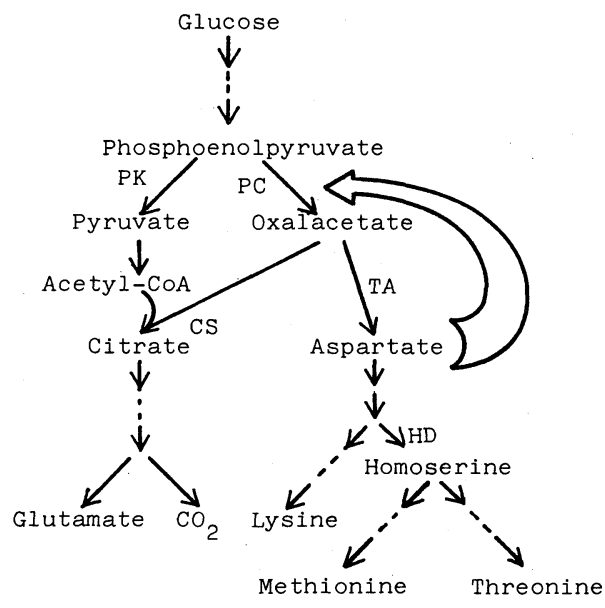

FIG. 1. Glucose Metabolism and Aspartate Biosynthesis in Brevibacterium flavum. , $^{3,11)}$

PK, pyruvate kinase; PC, phosphoenolpyruvate carboxylase; CS, citrate synthase; TA, aspartate aminotransferase; HD, homoserine dehydrogenase; $\Rightarrow$, feedback inhibition.

are summarized in Table I. Medium 34 was a modification of medium $25^{1)}$ and composed of $100 \mathrm{~g}$ of glucose, $40 \mathrm{~g}$ of $\left(\mathrm{NH}_{4}\right)_{2} \mathrm{SO}_{4}, 1 \mathrm{~g}$ of $\mathrm{KH}_{2} \mathrm{PO}_{4}, 0.4 \mathrm{~g}$ of $\mathrm{MgSO}_{4} \cdot 7 \mathrm{H}_{2} \mathrm{O}, 10 \mathrm{mg}$ of $\mathrm{FeSO}_{4} \cdot 7 \mathrm{H}_{2} \mathrm{O}, 8 \mathrm{mg}$ of $\mathrm{MnSO}_{4} \cdot 4 \mathrm{H}_{2} \mathrm{O}, 200 \mu \mathrm{g}$ of thiamine $\mathrm{HCl}, 2 \mathrm{ml}$ of Mieki (a commercial preparation from soybean-meal acid hydrolysate), $1 \mathrm{~g}$ of Casamino acid, $100 \mathrm{~g}$ of $\mathrm{CaCO}_{3}$ (separately sterilized), and $2 \mu \mathrm{g}$ of $d$-biotin in a total volume of 1 liter, $\mathrm{pH} 7.0$, and sterilized at $110^{\circ} \mathrm{C}$ for $10 \mathrm{~min}$. Medium 35 was composed of $100 \mathrm{~g}$ of glucose, $45 \mathrm{~g}$ of $\left(\mathrm{NH}_{4}\right)_{2} \mathrm{SO}_{4}, 1 \mathrm{~g}$ of $\mathrm{KH}_{2} \mathrm{PO}_{4}, 1 \mathrm{~g}$ of $\mathrm{MgSO}_{4} \cdot 7 \mathrm{H}_{2} \mathrm{O}$, $10 \mathrm{mg}$ of $\mathrm{FeSO}_{4} \cdot 7 \mathrm{H}_{2} \mathrm{O}, 8 \mathrm{mg}$ of $\mathrm{MnSO}_{4} \cdot 4 \mathrm{H}_{2} \mathrm{O}, 100 \mu \mathrm{g}$ of thiamine $\mathrm{HCl}$, soybean-meal acid hydrolysate containing $363 \mathrm{mg}$ of total nitrogen, $70 \mathrm{~g}$ of $\mathrm{CaCO}_{3}$ (separately sterilized), and $2.7 \mu \mathrm{g}$ of $d$-biotin in a total volume of 1 linter, adjusted to $\mathrm{pH} 7.2$ with $\mathrm{NaOH}$, and sterilized at $115^{\circ} \mathrm{C}$ for $10 \mathrm{~min}$. Compositions of medium $7,^{3)}$ medium $10^{3)}$ and medium $23^{1)}$ were reported in the previous papers.

Isolation of methionine-insensitive revertants. Mutant 1231 was cultured for $16 \mathrm{hr}$ in medium 7 without agar but supplemented with $5 \mathrm{~g}$ of monosodium glutamate per liter. Then, the cells were harvested, washed twice with $0.1 \mathrm{M}$ sodium phosphate buffer, $\mathrm{pH} 7.0$, treated with 250 to $750 \mu \mathrm{g} / \mathrm{ml}$ of $N$-methyl- $N^{\prime}$-nitro- $N$-nitrosoguanidine at $30^{\circ} \mathrm{C}$ for $15 \mathrm{~min}$, washed again twice with the buffer, and suspended in the buffer. The cell suspension (about $10^{6}$ cells $/ \mathrm{ml}$ ) was spread on medium 10 supplemented with $500 \mathrm{mg} /$ liter of methionine and incubated at $30^{\circ} \mathrm{C}$ for 5 days. The colonies appearing on the agar plates were picked up and their insensitivity to methionine further confirmed.

Aspartate production. A loopful of cells grown on medium 23 for $24 \mathrm{hr}$ was inoculated into a $500-\mathrm{ml}$ flask containing $20 \mathrm{ml}$ of medium 34 or 35 and cultured aerobically at $30^{\circ} \mathrm{C}$ for $72 \mathrm{hr}$ or $48 \mathrm{hr}$, respectively. Aspartate and glutamate produced were assayed microbiologically with Leuconostoc mesenteroides (ATCC8042) and Streptococcus faecalis (ATCC8043), respectively. Residual glucose was determined enzymatically using a "Glucose-B-Test" purchased from Wako Pure Chemical Industries. The growth was determined by measuring absorbancy at $562 \mathrm{~nm}$ after 26-fold dilution.

Enzyme preparation. B. flavum 2247 or its mutants were cultured aerobically at $30^{\circ} \mathrm{C}$ for $40 \mathrm{hr}$ in $500-\mathrm{ml}$ flasks containing $50 \mathrm{ml}$ of medium 34 containing $300 \mu \mathrm{g} / \mathrm{ml}$ of biotin, except that $4 \mathrm{~g} /$ liter of Casamino acid was added for strain 1-231.

A crude enzyme extract was prepared by sonic disruption of cells which had been washed twice with $0.2 \% \mathrm{KCl}$ and suspended in $50 \mathrm{~mm}$ Tris- $\mathrm{HCl}$ buffer, $\mathrm{pH} 7.5$, containing $0.1 \mathrm{M}\left(\mathrm{NH}_{4}\right)_{2} \mathrm{SO}_{4}$. The extract was passed through a Sephadex G-50 column equilibrated with $50 \mathrm{~mm}$ Tris$\mathrm{HCl}$ buffer, $\mathrm{pH} 7.5$, containing $0.5 \mathrm{M}\left(\mathrm{NH}_{4}\right)_{2} \mathrm{SO}_{4}$, when it was used for the enzyme assay.

PC was partially purified from the sonic extracts of $B$. 
flavum 2247 and its mutant, 70. The sonic extracts of 2247 prepared as above ( $844 \mathrm{mg}$ protein) were placed on a DEAE-cellulose column $(2.5 \times 33 \mathrm{~cm})$ previously equilibrated with $50 \mathrm{~mm}$ Tris- $\mathrm{HCl}$ buffer, $\mathrm{pH} \mathrm{7.5,} \mathrm{containing}$ $0.1 \mathrm{M}\left(\mathrm{NH}_{4}\right)_{2} \mathrm{SO}_{4}$. After the column was washed with $160 \mathrm{ml}$ of the same buffer containing $0.1 \mathrm{M} \mathrm{NaCl}$, the enzyme was eluted with a concentration gradient of $\mathrm{NaCl}$ formed from $800 \mathrm{ml}$ ( 5 column volumes) of the buffer containing $0.1 \mathrm{M} \mathrm{NaCl}$ and that containing $0.6 \mathrm{M} \mathrm{NaCl}$. The eluates from the column were immediately mixed with $0.5 \mathrm{M}\left(\mathrm{NH}_{4}\right)_{2} \mathrm{SO}_{4}$ (final concentration) to stabilize the enzyme. Fraction showing PC activity were pooled. PC was partially purified from the sonic extracts of strain 70 as described above except that the enzyme was eluted from the column with a concentration gradient of $\mathrm{NaCl}$ formed from $800 \mathrm{ml}$ of the buffer containing $0.1 \mathrm{M}$ $\mathrm{NaCl}$ and $800 \mathrm{ml}$ of the buffer containing $0.4 \mathrm{M} \mathrm{NaCl}$.

CS was partially purified from the sonic extracts of 2247 and 70 by DEAE-cellulose column chromatography as described above except that the enzymes were eluted from the column $(2.3 \times 12 \mathrm{~cm})$ with a concentration gradient of $\mathrm{NaCl}$ formed from $250 \mathrm{ml}$ of the buffer containing $0.1 \mathrm{M}$ $\mathrm{NaCl}$ and that containing $0.4 \mathrm{M} \mathrm{NaCl}$, and that the column for strain 70 was equilibrated with the buffer containing no $\left(\mathrm{NH}_{4}\right)_{2} \mathrm{SO}_{4}$.

Enzyme assay. The following enzyme activities were determined by measuring the initial rate of the reactions at 20 to $25^{\circ} \mathrm{C}$ with a Gilford-2600 recording spectrophotometer, after the reactions had been started by added the enzymes.

CS was assayed by the modified method of Srere et al., ${ }^{6)}$ in which the increase of absorbancy at $412 \mathrm{~nm}$ of the reaction mixture was measured. Reaction mixture A contained $70 \mathrm{~mm}$ Tris- $\mathrm{HCl}$ buffer, $\mathrm{pH} 8.0,0.1 \mathrm{~mm}$ oxalacetate (OAA), $0.05 \mathrm{~mm}$ acetyl-CoA (AcCoA), $0.05 \mathrm{~mm} 5,5^{\prime}$ dithiobis-(2-nitrobenzoic acid) (DTNB) and the enzyme. $^{3,10)}$ Reaction mixture B consisted of $70 \mathrm{~mm}$ Tris$\mathrm{HCl}$ buffer, pH 8.0, 1.0 mm OAA, 0.2 mm AcCoA, 0.05 mM DTNB and the enzyme.

PC activity was assayed by the same method as previously reported.9) The standard reaction mixture contained $100 \mathrm{~mm}$ Tris- $\mathrm{HCl}$ buffer, $\mathrm{pH}$ 7.5, $2 \mathrm{~mm}$ PEP, $3.3 \mathrm{~mm} \mathrm{MnSO}_{4}, 10 \mathrm{~mm} \mathrm{NaHCO}_{3}, 0.15 \mathrm{~mm} \mathrm{NADH}, 0.1$ $\mathrm{mm} \mathrm{AcCoA}, 10 \mu \mathrm{g}$ malate dehydrogenase (pig heart), and the enzyme in a final volume of $1.5 \mathrm{ml}$ at room temperature.

Methods for determining HD ("reverse reaction") ") and $\mathrm{PK}^{2)}$ were described previously, except that the $\mathrm{pH}$ of the PK assay medium was 7.5.

Chemicals. $\quad N$-Methyl- $N^{\prime}$-nitro- $N$-nitrosoguanidine, DTNB, OAA, Casamino acid and Mieki (soybean-meal acid hydrolysate) were purchased from Aldrich Chemical Company, Inc., Wako Pure Chemical Industries, Nutritional Biochemical Co., Difco Laboratories and Ajinomoto Co., respectively. L-Methionine, L-homoserine,
PEP and ADP were obtained from Sigma Chemical Co., and AcCoA, NADP, NADH, malate dehydrogenase (pig heart) and lactate dehydrogenase (rabbit muscle) from Boehringer Mannheim GmbH.

\section{RESULTS}

\section{Production of L-aspartate by pyruvate kinase mutants}

As reported previously, aspartate is accumulated only when the culture medium contains a limited amount of biotin. ${ }^{1)}$ Therefore, mutant 1-231 having low $\mathrm{PK}$, which was derived from the aspartate producer, 15-8, and produced lysine with excess biotin, was cultured in biotin-deficient media. However, the amount of aspartate produced was less than that by the parent strain, 15-8. Moreover, the mutant produced large amounts of lysine as a byproduct. Since the lysine production seems due to its low HD activity, ${ }^{8)}$ mutants having normal levels of HD activity were derived from strain 1-231. These mutants were isolated as methionine-insensitive revertants which grew on the medium supplemented with methionine, because growth of the parent strain 1-231 was inhibited by methionine and restored by threonine, probably owing to its low HD activity. ${ }^{4,8)}$ Figure 2 shows the distribution of these forty revertants as to their aspartate productivities. Under these conditions (glucose, $100 \mathrm{~g} /$ liter) the amount of aspartic acid produced by the original strain, 15-8, was $10 \mathrm{~g} /$ liter which was almost the same as that under the conditions described previously (glucose, $36 \mathrm{~g} /$ liter). Then, 28 of the tested revertants produced more aspartate than the original strain did. The best of them, 70, accumulated $22.6 \mathrm{~g}$ of $\mathrm{L}-$ aspartic acid/liter at maximum and its HD activity was restored to the level of that of strain $15-8$, but it lacked PK activity similar to the parent strain, 1-231 (Table II). Although it was reported previously that strain 1-2314) had low PK activity, the activity was not true PK activity, because it depended on PEP and not on another substrate, ADP, or on lactate dehydrogenase. The apparent activity may be due to the $\mathrm{PC}$ reaction coupled with 


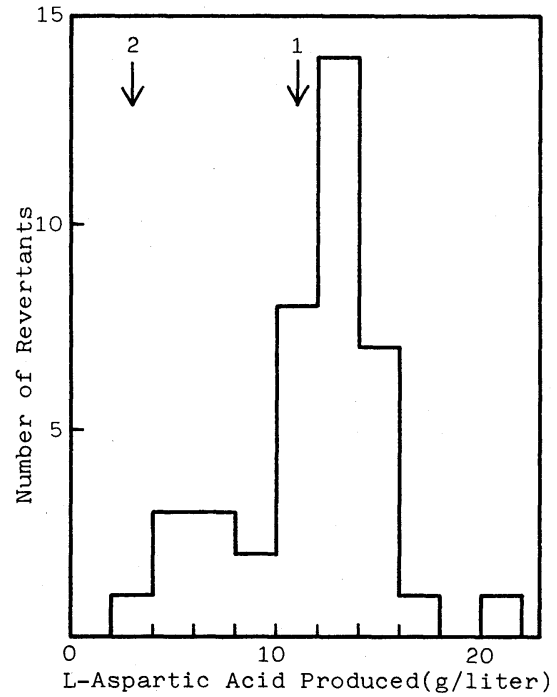

FIG. 2. Distribution of Aspartate Productivity of Methionine-insensitive Revertants from Strain 1-231.

The bacterial strains were aerobically cultured in medium 34 at $30^{\circ} \mathrm{C}$ for $72 \mathrm{hr}$, except that the medium containing $60 \mathrm{~g} /$ liter of $\left(\mathrm{NH}_{4}\right)_{2} \mathrm{SO}_{4}$ and supplemented with $500 \mathrm{mg} /$ liter of L-methionine and of L-threonine was used for strain 1-231. Arrows in the figure $(1,2 \rightarrow)$ show the aspartate productivities of strains $15-8$ and 1-231, respectively.

malate dehydrogenase in the crude extract because a large amount of the extract was used for the enzyme assay.

Figure 3 shows the time course of the aspartate production by strain 70 . Similar to the glutamate production by the wild strain, the aspartate production began after the growth had almost stopped, owing to biotin starvation. It reached the maximal level at $48 \mathrm{hr}$ when glucose had been consumed completely. After that, aspartate accumulated was not reduced. As shown in Fig. 4, the amount of aspartate produced by strain 70 clearly depended on that of biotin added to the culture medium, like the glutamate production by the wild strain. It reached 21.2 and $19.9 \mathrm{~g} /$ liter at the optimum and standard concentrations of biotin, 2.3 and $2.7 \mu \mathrm{g} /$ liter, respectively. Glutamate was also produced as a by-product, 7.0 and $6.4 \mathrm{~g} /$ liter under these conditions. On the other hand, wild strain 2247 produced only about $1 \mathrm{~g}$ of aspartate/liter under the standard conditions as under the previous conditions, ${ }^{1)}$
Table II. EnZyme Activities in Aspartate Producer, Strain 70, The Wild Strain, AND THE INTERMEDIATE MUTANTS

Specific activities of the enzymes were determined by the methods in MATERIALS AND METHODS using the crude enzyme extracts. The data in parentheses correspond to the main CS (Peak I) calculated from the ratios of the two peaks in Fig. 5 under conditions A and B.

\begin{tabular}{lrrrrrrr}
\hline & & \multicolumn{6}{c}{$\mathrm{CS}$} \\
\cline { 4 - 7 } Strain & HD & PK & \multicolumn{7}{c}{ PC $^{a}$} \\
\cline { 4 - 8 } & & & $\mathrm{A}^{b}$ & $\mathrm{~B}$ & $\mathrm{~B} / \mathrm{A}$ & $V m^{a}$ & \\
\hline 2247 & $-^{c}$ & 809 & 345 & 838 & 2.4 & 1360 & 351 \\
214 & - & 563 & 2 & 5 & 2.5 & - & - \\
$15-8$ & 0.70 & 624 & 5 & 58 & 11.6 & - & - \\
$1-231$ & 0.00 & 0 & 7 & 49 & 7.4 & - & - \\
70 & 1.11 & 2 & 16 & 76 & 4.7 & 680 & 515 \\
& & & $(7)$ & $(68)$ & $(9.8)$ & & \\
\hline
\end{tabular}

$\mathrm{nmol} / \mathrm{min} / \mathrm{mg}$-protein.

a Specific activity at saturated concentrations of substrates.

b Assay conditions A and B mean those using reaction mixtures A and B, respectively.

c Not determined.

For abbreviations, see the footnote to Table I.

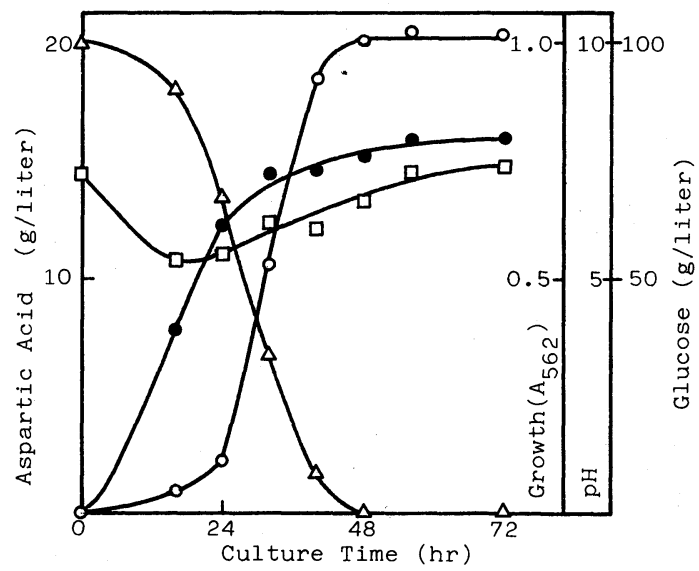

FIG. 3. Time Course of Aspartate Production by Strain 70.

Mutant 70 was aerobically cultured in medium 35 at $30^{\circ} \mathrm{C}$ for $72 \mathrm{hr}$.

-1 - growth; - - , L-aspartic acid; $-\triangle-$, glucose; $-\square-, \mathrm{pH}$.

while it produced $43 \mathrm{~g}$ of glutamate/liter under the former conditions, that is, much more than under the latter conditions, but with almost the same yield. 


\section{Citrate synthase}

It was described in the previous paper ${ }^{9)}$ that the original strain, 15-8, from which strain 70 was derived was a prototrophic revertant from CS-defective glutamate auxotroph 214 and had only very low CS activity. However, as described above, strain 70 accumulated a considerable amount of glutamate as a byproduct, whose biosynthesis was catalyzed by $\mathrm{CS}$ at the first specific step (Fig. 1). Therefore, $\mathrm{CS}$ activities of a series of mutants were exam-

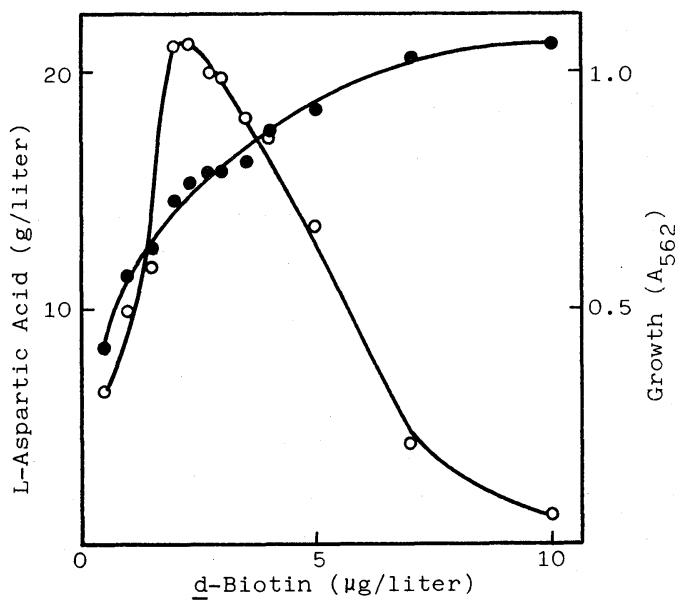

FIG. 4. Effects of B1otin on Aspartate Production.

Mutant 70 was aerobically cultured in medium 35 containing the indicated concentrations of $d$-biotin at $30^{\circ} \mathrm{C}$ for $48 \mathrm{hr}$. - $\mathrm{O}-$, L-aspartic acid; - - - growth. ined. As shown in Table II (assay conditions A), the activity of strain 70 was higher than that of strain 15-8 but less than one-twentieth of that of the wild strain under the conventional standard conditions. However, when CS activity was determined at high concentrations of substrates (conditions $\mathrm{B}$ ), that of strain 70 was found to be considerably restored to one-eleventh. Moreover, the activities of strain 70 and the wild strain at saturated concentrations of the two substrates $(\mathrm{Vm})$ were 680 and $1360 \mathrm{nmol} / \mathrm{min} / \mathrm{mg}$ protein, respectively, that is, the activity of strain 70 was restored to about $1 / 2$ that of the wild strain. As these results indicated that Michaelis constants $(\mathrm{Km})$ for the substrates as well as the activities of CS were altered by the mutations, CSs of strain 70 and the wild strain were partially purified by DEAE-cellulose column chromatography (Fig. 5) and their $\mathrm{Km}$ values examined. Table III shows that $\mathrm{Km}$ values for OAA and AcCoA of the mutant enzyme were 110 and 6 times as high as those of the wild-type enzyme, respectively, whereas the rate equation was the same as that for the latter. ${ }^{10)}$ Then, the $\mathrm{B} / \mathrm{A}$ ratios of the series of mutants were compared with one another, in order to clarify the mutation step at which the high $\mathrm{Km}$ values of CSs in strain 70 appeared. As shown in Table II, the B/A ratio of strain

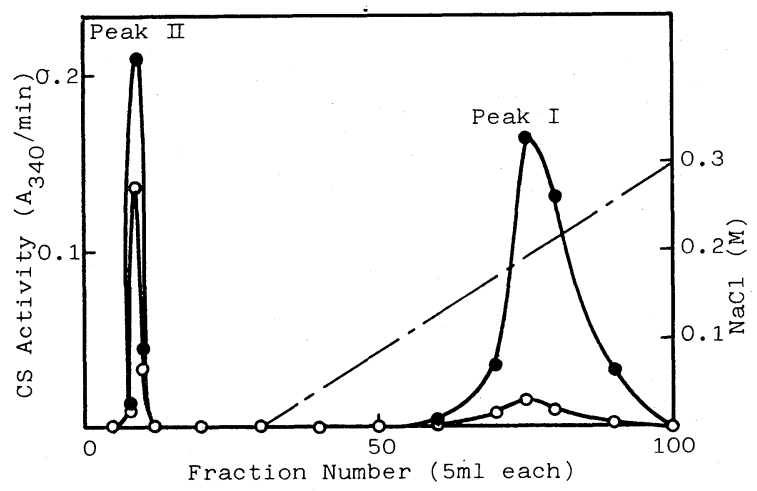

FIG. 5. Elution Profile of Citrate Synthase on DEAE-Cellulose Column Chromatography of Mutant Crude Extracts.

The sonic extracts of mutant 70 were subjected to DEAE-cellulose column chromatography with gradient elution with 0.1 to $0.4 \mathrm{M} \mathrm{NaCl}(---$, calculated concentration). Citrate synthase activities were determined under conditions A (- - : $0.1 \mathrm{~mm}$ OAA, $0.05 \mathrm{~mm} \mathrm{AcCoA})$ and B (- - : $1.0 \mathrm{~mm}$ OAA, $0.2 \mathrm{~mm} \mathrm{AcCoA}$ ). Details are given in MATERIALS AND METHODS. 
Table III. Michaelis Constants of Citrate Synthase from the Mutant and Wild Strains

Michaelis constants of CS were obtained from double reciprocal plots of the initial reaction rate against the substrate concentration in the presence of various concentrations of another substrate. The partially purified enzymes were used.

\begin{tabular}{ccc}
\hline \multirow{2}{*}{ Strain } & \multicolumn{2}{c}{$K m$} \\
\cline { 2 - 3 } & $\begin{array}{c}\text { Oxalacetate } \\
(\mu \mathrm{M})\end{array}$ & $\begin{array}{c}\text { Acetyl-CoA } \\
(\mu \mathrm{M})\end{array}$ \\
\hline 2247 (Wild) & 2.7 & 50 \\
70 & 300 & 320 \\
\hline
\end{tabular}

214 was the same as that of the wild strain, whereas the ratio of revertant 15-8 was markedly higher than that. The $\mathrm{B} / \mathrm{A}$ ratio was then reduced at the step of strain 70 . The elution profile of CS from strain 70 on DEAE-cellulose column chromatography (Fig. 5) showed the presence of two CSs; the main CS (Peak I) was eluted similar to the wild-type CS, while the minor CS (Peak II) was not adsorbed. The activity of minor CS was not negligible, especially when that of crude extracts was determined under conditions $\mathrm{A}$. The main CS activity in the crude extract was calculated on the basis of these relative values and found to be almost the same as the CS activity of the parent strain, 1-231, under conditions $\mathrm{A}$. Then, the $\mathrm{B} / \mathrm{A}$ ratio of the main $\mathrm{CS}$ from strain 70 was nearly equal to that of strain 15-8. The results also suggest that the second minor CS appeared or was markedly increased when strain 70 was derived, because the minor CS activity could not be detected in the extract of strain 2247.

\section{Phosphoenolpyruvate carboxylase}

As the preliminary experiment ${ }^{4)}$ revealed that PC from strains 15-8 and 1-231 was lesssensitive to the feedback inhibition by aspartate than the wild-type enzyme, the enzyme from strain 70 was partially purified by DEAE-cellulose column chromatography and its regulatory properties were compared with those of the wild strain in further detail.

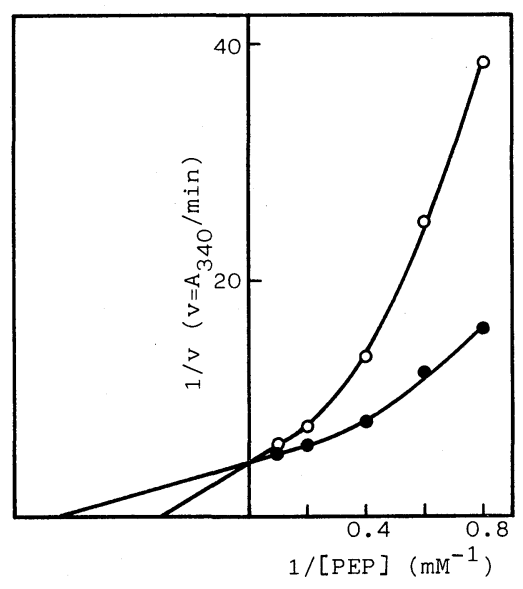

FIG. 6. Double Reciprocal Plots of Phosphoenolpyruvate Carboxylase Reaction Rate against Phosphoenolpyruvate Concentration.

The experimental conditions were given in MATERIALS AND METHODS except that PEP concentrations were as indicated in the figure. The partially purified enzymes from strains 2247 ( - O - ) and 70 (- - - ) were used.

\section{Table IV. Kinetic Constants of Phosphoenol- pyruvate Carboxylase from the Mutant AND WiLd STRaINS}

$K m$ (a) and $K m$ (b) are Michaelis constants of phosphoenolpyruvate carboxylase obtained from double reciprocal plots of the initial reaction rate against the substrate concentration (Fig. 6) and Hill plots replotted with the data in Fig. 6. $S_{0.5}$ is the phosphoenolpyruvate concentration giving the half maximum rate, estimated from Fig. 6 .

\begin{tabular}{ccc}
\hline \multirow{2}{*}{ Strain } & \multicolumn{2}{c}{ Phosphoenolpyruvate $(\mathrm{mM})$} \\
\cline { 2 - 3 } & 2247 & 70 \\
\hline$K m(\mathrm{a})$ & 3.4 & 1.5 \\
$K m(\mathrm{~b})$ & 9.6 & 3.4 \\
$S_{0.5}$ & 3.0 & 1.9 \\
\hline
\end{tabular}

As shown in Fig. 6, double-reciprocal plots of $\mathrm{PC}$ reaction rate against the concentration of substrate PEP were not linear with the same Hill coefficient $(n=2.1)$ as in the case of the wild strain. On the other hand, the apparent Michaelis constant obtained from the linear part of the plots at high concentrations of PEP was $1.5 \mathrm{mM}$, that is, lower than that of the wild strain $(3.4 \mathrm{~mm})$. This indicates that the affinity for the substrate in- 


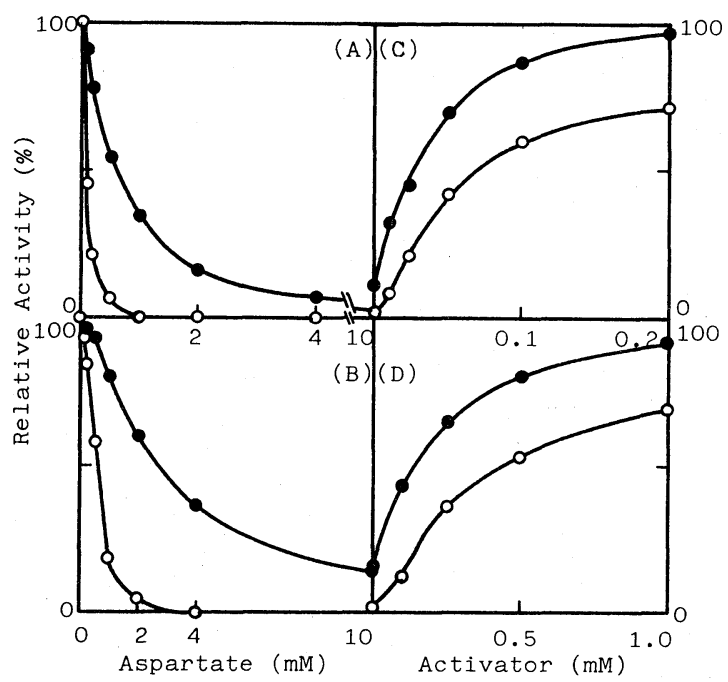

FIG. 7. Effects of Aspartate (A and B), Acetyl-CoA (C) and Fructose-1,6-bisphosphate (D) on Phosphoenolpyruvate Carboxylase Activities.

The experimental conditions were as given in Materials and Methods, and the partially purified enzymes from strains 2247 (- - -) and 70 (- - ) were used, but in (A), the reaction mixture did not contain AcCoA but the indicated concentrations of aspartate; in (B), the mixture contained $0.2 \mathrm{mM}$ PEP and the given concentrations of aspartate; in (C) and (D), the PEP concentration was $0.2 \mathrm{mM}$ and the indicated concentrations of AcCoA and FBP were added to the reaction mixture, respectively, instead of $0.1 \mathrm{~mm}$ AcCoA. A relative activity of $100 \%$ was taken as the activity in the absence of L-aspartate, in (A) and (B), and that at saturated concentrations of the activators, in (C) and (D), which was obtained from the double reciprocal plots of the reaction rate against the activator concentration.

creased. PC from strain 70 was less-sensitive to the feedback inhibition by aspartate than that from the wild strain, whether the activator, AcCoA, was present or not. The concentrations of aspartate giving $50 \%$ inhibition were 6.2- and 4.5-fold higher in the absence and presence of $\mathrm{AcCoA}$, respectively (Figs. $7 \mathrm{~A}$ and $\mathrm{B}$ ). The mutant enzyme was activated more easily by the activators, AcCoA and fructose-1,6-bisphosphate (FBP), than the wild-type enzyme (Figs. 7C and D). The concentrations of the activators giving half maximum activation were about $1 / 3$ of that for the wild-type enzyme. Moreover, as shown in Table II, the specific activity of the crude extract of strain 70 at a saturated concentration of the substrate, PEP, $(\mathrm{Vm})$ was 1.5fold higher than that of the wild strain.

\section{DISCUSSION}

A lack of PK increased the amount of L- aspartic acid produced about 2-fold, from $10 \mathrm{~g} /$ liter (strain 15-8) to $22.6 \mathrm{~g} /$ liter (strain 70). This concentration of accumulated aspartate is the highest among those for fermentation processes reported.

As described in the previous papers, ${ }^{1 \sim 3)}$ aspartate biosynthesis is regulated by the feedback inhibition of PC, whose substrate, PEP, is metabolized and consumed not only by the $\mathrm{PC}$ reaction but also by the $\mathrm{PK}$ reaction competing with it. Although PC of strain 15-8 is lesssensitive to the feedback inhibition by aspartate than that of the wild strain, the inhibition still remains. Therefore, it seems that an increase in the concentration of substrate, PEP, caused by a lack of PK decreased feedback inhibition of PC competitively resulting in the increase in aspartate overproduction.

In the previous paper, ${ }^{11)}$ it was concluded that the PK reaction was the cnly pyruvateforming reaction from glucose, bacause PKlacking mutants derived directly from the wild 
strain were selected as mutants which could not grow on glucose but on acetate. However, strain 70 obtained in this study grew well on glucose-minimal medium in spite of its lack of PK. This difference seems to be due to other mutations in strain 70 .

PC from strain 70 was less-sensitive to the feedback inhibition by aspartate than the wildtype enzyme, similar to the case of the enzyme from the original strain, 15-8.4) Moreover, the enzyme from strain 70 showed higher affinities for the substrate, PEP, as well as the activators, AcCoA and FBP, than the wild-type enzyme.

Since the activators as well as the substrate competitively reverse the aspartate inhibition, while they promote binding of the substrate and the enzyme to each other, ${ }^{2)}$ a single mutation which increased the enzyme affinity for the activators or for the substrate could explain all the enzymatic alterations above. However, the finding that partial desensitization to the feedback inhibition was also observed without the activators excluded the former possibility.

Furthermore, the latter case, a single mutation in the substrate binding site on PC can also explain the increased specific acitivity of $\mathrm{PC}$ in the mutant.

Consistent with the preliminary experiment, ${ }^{9)}$ the CS activity of strain $15-8$, a prototrophic revertant derived from a CS-defective glutamate auxotroph, strain 214 , was only about 3-fold that of the parent under standard conditions A. However, it was found to be more than 12-fold under high-substrate conditions $\mathrm{B}$, and, moreover, to be almost half that of the wild strain under the substrate-saturated conditions as shown by strain 70, because of its high $\mathrm{Km}$ values for the substrates, especially OAA. This result may explain the good growth of strains $15-8^{1)}$ and 70 in the absence of glutamate, if the intracellular concentration of OAA was similar to or higher than the $K m$ value $(300 \mu \mathrm{M})$. The intracellular concentration of OAA in the wild strain, however, seems much lower than this value, because the preferential synthesis of glutamate to aspartate, as shown by the con- trol experiment with the wild strain in Fig. 3 (43 and $1.3 \mathrm{~g} /$ liter, respectively), has been attributed to the difference between the $\mathrm{Km}$ values for OAA of CS and aspartate aminotransferase (TA) (3 and $110 \mu \mathrm{M}$, respectively $)^{12)}$ (Fig. 1). On the other hand, OAA concentrations in the mutants are probably much higher than that in the wild strain, because the feedback inhibition of PC which regulates the intracellular concentration of OAA has been reduced by the mutation. These results suggest that the desensitization of PC to the feedback inhibition was necessary for revertant 15-8 having CS with high $\mathrm{Km}$ values to grow well without glutamate and, therefore, it was not an incidental alteration accompanied by the restoration of the CS activity in the mutation.

The high $\mathrm{Km}$ values of CSs in these mutants seem to cause preferential synthesis of aspartate in contrast to that of glutamate in the wild strain (the aspartate/glutamate ratios were 3.1 and 0.03 respectively). The results support the previous suggestion ${ }^{12}$ ) that preferential synthesis of glutamate in the wild strain may be due to the lower $\mathrm{Km}$ value of CS than that of TA.

Acknowledgment. The authors are indebted to Dr. $\mathrm{H}$. Okada and Dr. R. Tsugawa of their laboratories for the encouragement during this study.

\section{REFERENCES}

1) I. Shiio, H. Ozaki and K. Ujigawa-Takeda, Agric. Biol. Chem., 46, 101 (1982).

2) H. Ozaki and I. Shiio, J. Biochem., 66, 297 (1969).

3) I. Shiio and K. Ujigawa, J. Biochem., 84, 647 (1978).

4) H. Ozaki and I. Shiio, Agric. Biol. Chem., 47, 1569 (1983).

5) I. Shiio, S. Ôtsuka and T. Tsunoda, J. Biochem., 46, 1597 (1959).

6) P. A. Srere, H. Brazil and L. Gonen, Acta Chem. Scand., 17, S129 (1963).

7) R. Miyajima, S. Ôtsuka and I. Shiio, J. Biochem., 63, 139 (1968).

8) I. Shiio and K. Sano, J. Gen. Appl. Microbiol., 15, 267 (1969).

9) I. Shiio and K. Ujigawa-Takeda, Agric. Biol. Chem., 43, 2479 (1979).

10) I. Shiio, H. Ozaki and K. Ujigawa, J. Biochem., 82, 395 (1977). 
11) A. Ôyama and I. Shiio, Abstracts of Papers, the 42nd Annual Meeting of the Japanese Biochemical Society 1969, p. 535.
12) I. Shiio, M. Mori and H. Ozaki, Agric. Biol. Chem., 46, 2967 (1982). 